Anna Mazurkiewicz-Pizto

Akademia Wychowania Fizycznego Józefa Pilsudskiego w Warszawie

Wojciech Pizło

Szkoła Gtówna Gospodarstwa Wiejskiego w Warszawie

\title{
Tajemniczy klient jako metoda badawcza - wybrane problemy
}

\section{MYSTERY SHOPPING AS THE RESEARCH METHOD - SELECTED PROBLEMS}

Specyfika ustug implikuje konieczność monitorowania ich jakości. Stale poszukiwane sq metody oceny ushug nieangażujace konsumentów. Jednq z nich jest metoda tajemniczego klienta. Celem publikacji jest diagnoza procedur stosowanych $w$ badaniach marketingowych, a $w$ szczególności wykorzystanie metody tajemniczego klienta $w$ której ocena jest prowadzona przez zespół osób. Dla sprawdzenia tego podejścia zastosowano ocene jakości ustug gastronomicznych w wybranych placówkach sieci restauracji, takich jak: Pizza Hut, Pizzeria Da Grasso, Bobby Burger $i$ Bierhalle. Innowacja $w$ badaniu byto wykorzystanie grupowej oceny ustugi. Przyjęta metodyka pozwoliła na przeprowadzenie badania w zbliżonych do rzeczywistych warunków, gdyż zwykle ludzie ida do restauracji w kilka osób. Budowanie zespołów, które wspólnie oceniałyby jakość usług, daje również możliwość redukcji zróżnicowanej percepcji i różnych doświadczeń osób uczestniczqcych $w$ badaniu.

Słowa kluczowe: metody badawcze, fenomenologia, pozytywizm, obserwacja uczestnicząca, badania marketingowe, konsument, usługi, mystery shopper, E. Husserl, A. Comte

\section{Wstęp}

W latach 90. XX w. w Polsce na skutek przemian politycznych i gospodarczych, nastąpiło umiędzynarodowienie dostawców usług badawczych. Wprowadzenie nowych reguł rynkowych sprawiło, że wiele podmiotów z branży badawczej, oferującej zbieranie informacji marketingowych miało ułatwione rozpoczęcie działalności w naszym kraju. Dla konsumentów w Polsce możliwość uczestniczenia w badaniach marketingowych było zjawiskiem wcześniej niespotykanym. W pierwszym okresie korzystano głównie z badań ilościowych takich jak różnego rodzaju ankiety. Potem wraz z rozwojem infrastruktury badawczej stosowano także ankiety internetowe, wywiady indywidualne oraz grupowe. Z kolei rozwój i upowszechnienie Internetu, w końcu lat 90. XX w. spowodował systematycznie rosnącą liczbą aktywnych użytkowników sieci, co stworzyło możliwości przeniesienia różnorodnych działań marketingowych, w tym badawczych, do środowiska wirtualnego, znacznie przyspieszając zbieranie informacji rynkowych. Dane zaczęto zbierać $\mathrm{z}$ pomocą, np. computer-assisted telephone interviewing, czyli wspomagany komputerowo wywiad telefoniczny CATI czy computer-assisted web interviewing (CAWI). Początek XXI wieku, dzięki rozwojowi 
nowoczesnych technologii, umożliwił zwiększenie rozpoznania indywidualnych potrzeb nabywców, budowanie baz danych oraz możliwość głębokiej i szybkiej analizy spowodowało wyłonienie się tzw. "insight management", stwarzające potencjał dokładniejszego wglądu w potrzeby, emocje i oczekiwania nabywców.

W badaniach marketingowych wykorzystuje się różne metody w celu poszukiwania prawdy o zjawiskach rynkowych. Polegają one na pozyskiwaniu informacji, aby zarządzający organizacjami mogli podejmować trafne decyzje odnoszące się do efektywnego wykorzystywania swoich zasobów i realizacji celów. Zapotrzebowanie na konkretny rodzaj informacji zależy od rodzaju problemu, który menedżerowie muszą rozwiązać. Badania marketingowe nie dotyczą tylko przedsiębiorstw, ale obejmują znacznie szerszy kragg zainteresowanych takich jak: instytucje rządowe, samorządy, partie polityczne, organizacje non-profit i szereg innych podmiotów. Można zatem wskazać, że badania marketingowe ${ }^{2}$ to całokształt działań, których celem jest uzyskanie informacji potrzebnych do usprawnienia procesów decyzyjnych $\mathrm{w}$ organizacji. Złożoność rynku, szybko zachodzące zmiany w otoczeniu rynkowym, silna konkurencja, zmieniające się oczekiwania i zwyczaje nabywców powodują coraz większe trudności w realizacji celów organizacji, dlatego ważne jest, aby stale rozwijać metody badawcze monitorujące oczekiwania i potrzeby nabywców.

\section{Badania marketingowe - przegląd literatury}

W literaturze przedmiotu wymienia się wiele podziałów badań marketingowych ${ }^{3}$. Jednym z wcześniejszych, dokonanych pod koniec lat 70 . XX w., było rozróżnienie badań marketingowych na badania defensywne, pasywne i ofensywne ${ }^{4}$. Badania defensywne prowadzone są $w$ celu uniknięcia nieprzewidywalnych wydarzeń biznesowych. W tym celu monitoruje się otoczenie i przewiduje ewentualne zagrożenia, które mogą wydarzyć się na rynku. Pozwalają one dostrzec większe zmiany w otoczeniu organizacji. Badania pasywne polegają na zbieraniu i porównywaniu danych własnych z konkurencją i używaniu ich do ustalania celów swojej organizacji. Z kolei badania ofensywne są podstawą do identyfikacji szans, które bez procesu badawczego mogłyby nie być zdiagnozowane. Inny podział badań uwzględnia dwa paradygmaty: fenomenologiczny i pozytywistyczny, które w znaczący sposób różnicują kwestie zbierania danych i ich interpretację. Paradygmat fenomenologiczny koncentruje się na subiektywnym znaczeniu badanego tematu. Autorem tej koncepcji, powstałej w XX wieku był E. Husserl, który głosił pogląd, że możliwości poznawcze człowieka wynikają z jego zdolności docierania do istoty zjawisk, a nie jak twierdzili pozytywiści, $\mathrm{z}$ wszelkich procedur empirycznych. Husserl podkreślał zdolność tzw. intuicji ejdetycznej ${ }^{5}$

\footnotetext{
${ }^{1}$ Marketing research tools and techniques, Nigel Bradley, Oxford University Press, 2013, p. 4-5.

${ }^{2}$ Mazurkiewicz-Pizło A., Pizło W., Marketing, Wiedza ekonomiczna i aktywność na rynku, wyd. Naukowe PWN, Warszawa 2017, s. 69-85.

${ }^{3}$ M.J. Schmidt, S. Hollenson Marketing research. An international approach, FT Prentice Hall, 2006, Marketing research, tools and techniques, Nigel Bradley, Oxford University Press, 2013, oraz Crouch S., Housden M., Marketing Research for Mangers, Routledge Francis and Taylor 2003.

${ }^{4}$ Marketing research, tools and techniques, Nigel Bradley, Oxford University Press, 2013, p. 4-5.

${ }^{5}$ J. Szacki, Historia myśli socjologicznej, Wyd. Naukowe PWN, Warszawa 2012, s. 481-484.
} 
w paradygmacie fenomenologicznym, który koncentruje się na faktach i przyczynach zjawisk społecznych ${ }^{6}$. Twierdził, że jedynie metoda rozpoczynająca badanie uniezależnione od jakiejkolwiek teorii może stanowić właściwą podstawę do dalszych analiz $^{7} \mathrm{Z}$ kolei w paradygmacie pozytywistycznym, którego tezę sformułował A. Comte w XIX w., podstawą było twierdzenie, że prawdziwa wiedza opiera się wyłącznie na zdobytej empirycznie, pozytywnie zweryfikowanej metodą naukowa, teorii naukowej. Zatem badania jakościowe odnoszą się do paradygmatu fenomenologicznego, a badania ilościowe opierają się na paradygmacie pozytywistycznym. Różnice w procesach badawczych jednego i drugiego typu są znaczące, np. struktura badań, sposób uzyskiwania informacji, sposób analizy etc. (patrz tabela 1).

Tabela 1. Porównanie badań jakościowych i ilościowych

\begin{tabular}{|l|l|}
\hline \multicolumn{1}{|c|}{ Jakościowe } & \multicolumn{1}{c|}{ Ilościowe } \\
\hline $\begin{array}{l}\text { Koncentrują się na wyrazach, narracji, } \\
\text { koncepcjach, obrazach. }\end{array}$ & Koncentrują się na liczbach. \\
\hline Analiza rozpoczyna się podczas zbierania danych. & Analiza rozpoczyna się po zebraniu wszystkich danych. \\
\hline $\begin{array}{l}\text { Analizy dopasowywane do każdego projektu, } \\
\text { nieustrukturyzowane. }\end{array}$ & $\begin{array}{l}\text { Wykorzystanie standardowych technik. } \\
\text { Ustrukturyzowane. }\end{array}$ \\
\hline Oryginalny sposób komunikacji wyników & Standardowy sposób komunikowania wyników \\
\hline $\begin{array}{l}\text { Cechy badań: miękkie, elastyczne, subiektywne, } \\
\text { polityczne, studia przypadków, spekulatywne, } \\
\text { ugruntowane w rzeczywistości. }\end{array}$ & $\begin{array}{l}\text { Cechy badań: twarde, ustrukturyzowane, obiektywne, } \\
\text { wolne od wartościowania, sondaże, testujące hipotezy, } \\
\text { abstrakcyjne. }\end{array}$ \\
\hline
\end{tabular}

Źródło: Marketing research, tools and techniques, Nigel Bradley, Oxford University Press, 2013, s. 15 oraz D. Silverman, Interpretacja danych ilościowych, Wyd. Naukowe PWN, Warszawa, 2009, s. 39.

Do głównych metod badawczych stosowanych w badaniach jakościowych należą: obserwacja, analiza tekstów i dokumentów, wywiady oraz nagrywanie i transkrybowanie. Metody te zwykle stosuje się komplementarnie, np. wywiad często łączony jest $\mathrm{z}$ obserwacją, a analiza dokumentów z wywiadem. Każda z wymienionych metod może być stosowana również $\mathrm{w}$ badaniach ilościowych. Metody są bowiem technikami, które nabierają stosownego znaczenia w zależności od wybranej metodyki badañ $^{8}$. Wprawdzie w badaniach ilościowych metoda obserwacji nie stanowi znaczącej techniki zbierania danych, ponieważ trudno ją przeprowadzić na dużych próbach, jednak w pewnych warunkach może być również przydatna. U podstaw prowadzenia badań jakościowych leży teoria ugruntowana, której początki sięgają lat 60. XX wieku. Opiera się ona na trzech fundamentalnych zasadach':

1. Badania terenowe należy rozpoczynać bez przyjmowania wstępnych hipotez. Pozwala to dostrzec sytuację $\mathrm{w}$ terenie, taką, jaką jest w rzeczywistości i wyeliminować wpływ istniejących teorii.

2. Należy stale porównywać ze sobą zebrane fragmenty materiałów empirycznych. Prowadzi to do określenia kodów, służących uporządkowaniu i

\footnotetext{
${ }^{6}$ Marketing research tools and techniques, Nigel Bradley, Oxford University Press, 2013, p.15.

${ }^{7}$ S. Judycki, Epistemologia XX wieku: przegląd stanowisk, Roczniki Filozoficzne, 1998/199, 46/47, s. 28

${ }^{8}$ D. Silverman, Interpretacja danych ilościowych, Wyd. Naukowe PWN, Warszawa, 2009, s. 39.

${ }^{9}$ P. Hensel, B. Glinka, Teoria ugruntowana, w: Badania jakościowe. Podejścia i teorie, tom 1, Wyd. Naukowe PWN, Warszawa 2012, s. 89
} 
zinterpretowaniu danych w celu wyróżnienia najważniejszych kategorii, z których zbudowana będzie teoria dotycząca badanego zjawiska.

3. Subiektywne pobieranie prób badawczych, polegające na takim wyborze osób i grup, aby poszerzyć znajomość problemu badawczego. W przeciwieństwie do klasycznych metod badań, w których dąży się do uzyskania prób reprezentatywnych. (tabela 2 ).

Tabela 2. Porównanie zastosowania wybranych metod w badaniach ilościowych i jakościowych

\begin{tabular}{|l|l|l|}
\hline \multicolumn{1}{|c|}{ Metody } & \multicolumn{1}{|c|}{ Badania ilościowe } & \multicolumn{1}{c|}{ Badania jakościowe } \\
\hline Obserwacja & $\begin{array}{l}\text { Prace wstępne, np. sformułowanie } \\
\text { problemu badawczego, wstępna lista pytań } \\
\text { w kwestionariuszu. }\end{array}$ & $\begin{array}{l}\text { Podstawa zrozumienia zachowań } \\
\text { wybranych grup społecznych, ważne dla } \\
\text { zrozumienia innych kultur. }\end{array}$ \\
\hline $\begin{array}{l}\text { Analizy } \\
\text { tekstualne }\end{array}$ & $\begin{array}{l}\text { Analizy treści, np. zliczenie i klasyfikacja } \\
\text { informacji według kategoryzacji przyjętej } \\
\text { przez badacza. }\end{array}$ & $\begin{array}{l}\text { Próba zrozumienia kategorii stosowanych } \\
\text { przez uczestników życia społecznego. }\end{array}$ \\
\hline Wywiady & $\begin{array}{l}\text { Badania sondażowe: głównie pytania } \\
\text { zamknięte na losowo dobranych próbach }\end{array}$ & $\begin{array}{l}\text { Pytania otwarte na małych próbach. } \\
\text { Badania fokusowe. }\end{array}$ \\
\hline $\begin{array}{l}\text { Nagrania audio } \\
\text { i wideo }\end{array}$ & $\begin{array}{l}\text { Używane rzadko do sprawdzenia precyzji } \\
\text { zapisu wywiadu. }\end{array}$ & $\begin{array}{l}\text { Konieczne do zrozumienia jak } \\
\text { konsumenci organizują swoją } \\
\text { wypowiedź, ruchy ciała. }\end{array}$ \\
\hline
\end{tabular}

Źródło: opracowanie własne na podstawie D. Silverman, Interpretacja danych ilościowych, Wyd. Naukowe PWN, Warszawa, 2009, s. 39.

Kolejny podział badań, z którym można spotkać się w literaturze, wyróżnia badania eksploracyjne (ang. eksploratory) i rozstrzygające (ang. conclusive). Badania eksploracyjne, czyli wstępne, mają na celu rozwinięcie początkowych przeczuć lub wyobrażeń (intuicji), aby dostarczyć kierunku kolejnych, koniecznych badań. Podstawowym celem badań wstępnych jest naświetlenie specyfiki sytuacji, zidentyfikowanie podstawowych obiektów badan oraz potrzeb badawczych w kolejnych działaniach. Są użyteczne wówczas, gdy menedżer podejmujący decyzję potrzebuje lepszego zrozumienia sytuacji lub identyfikacji alternatywnych decyzji. Z kolei badania rozstrzygające (zwane również potwierdzającymi) mają na celu weryfikację spostrzeżeń i wsparcie menedżerów podejmujących decyzję w określonym obszarze działania.. Podstawowym celem badań rozstrzygających jest pomoc menedżerom w podjęciu właściwych działań w określonej sytuacji biznesowej. Są one szczególnie użyteczne, gdy podejmujący decyzje ma kilka alternatyw postępowania i szuka informacji mogących rozstrzygnąć dokonanie najwłaściwszego wyboru. Badania rozstrzygające są zwykle bardziej rygorystyczne i sformalizowane niż badania wstępne, ponieważ są ściśle sprecyzowane i mają na celu wspomóc ostatni etap procesu decyzyjnego (tabela 8$)^{10}$.

\section{Proces badań marketingowych}

W każdej organizacji powinien być opracowany system pozyskiwania i zbierania informacji przydatnych $\mathrm{w}$ prowadzeniu m.in. działań marketingowych. Jak już wspomniano wcześniej, informacje mogą pochodzić ze źródeł wtórnych oraz

\footnotetext{
${ }^{10}$ A. Parasuraman, Dhruv Grewal, R. Krishnan, Marketing Research, Houghton Mifflin Company, Boston, New York, 2011, p. 56.
} 
pierwotnych. Wykorzystanie tych pierwszych nie nastręcza dużego wysiłku, wymaga bowiem głównie umiejętności poszukiwania, przetwarzania i selekcji znalezionych danych. Biorąc powyższe pod uwagę, pierwszy etap planowania badań marketingowych $\mathrm{z}$ wykorzystaniem omawianych danych, powinien koncentrować się na sprecyzowaniu kluczowych, potrzebnych informacji, niezbędnych $\mathrm{w}$ procesie podejmowania decyzji. Następnie należy poszukać potencjalnych źródeł informacji, z których można je uzyskać. Ostatecznie w trzecim etapie, po analizie i odrzuceniu danych niepotrzebnych, uzyskuje się kluczowe informacje dla rozwiązania postawionego problemu. Proces badawczy, w którym wykorzystuje się istniejące już wyniki badań i informacje opracowane dla innych celów, znacznie skraca czas oczekiwania na rozstrzygnięcie problemu. Ponadto, jego przeprowadzenie, jest znacznie mniej kosztowne i wymaga zaangażowania mniejszej liczby osób w proces badawczy. Ze względu na wysokie koszty prowadzenia badań marketingowych, w pierwszej kolejności należy wykorzystywać źródła wtórne. Dopiero w sytuacji, gdy dane z tych źródeł są niewystarczające, bo nie pozwalają na rozstrzygnięcie problemu, warto przeprowadzić badania pierwotne.

Rysunek 1. Etapy pozyskiwania informacji marketingowych $\mathrm{z}$ wykorzystaniem źródeł pierwotnych

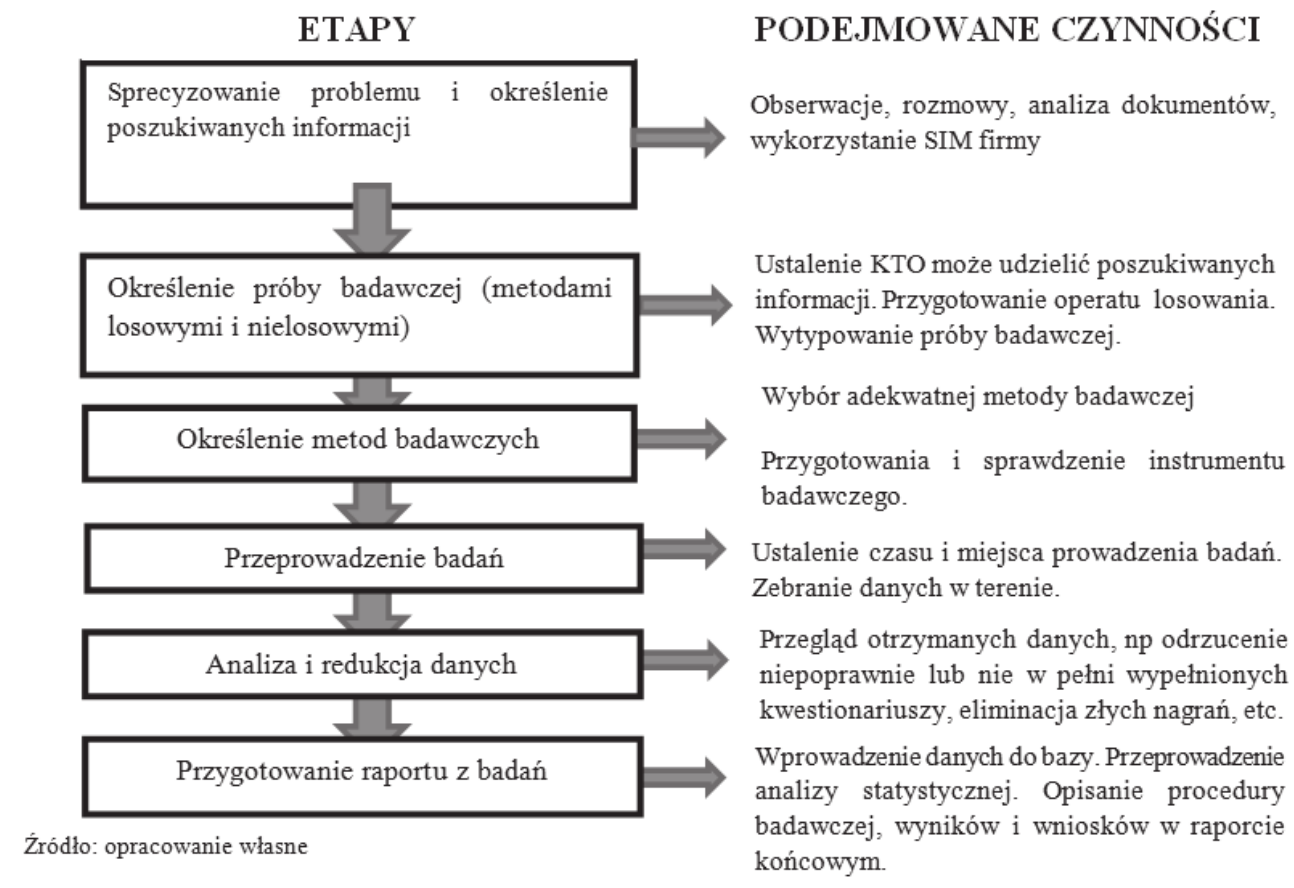

\section{Metody badań marketingowych}

W rozwiązywaniu problemów marketingowych ważny jest dobór właściwych metod badawczych. Badania marketingowe oparte są na narzędziach badawczych zaczerpniętych z ekonomii, socjologii i psychologii. Najbardziej znane są metody sondażowe, w których wykorzystuje się takie instrumenty badawcze jak ankiety. W 
praktyce, w zależności od potrzeb, stosuje się ankietę internetową bezpośrednią, prasową, audytoryjną, opakowaniową. Ponadto wykorzystuje się wywiady o różnym stopniu standaryzacji: od wywiadu swobodnego (rozmowy) do wywiadu o wysokim stopniu standaryzacji, polegającego praktycznie na odczytaniu pytań ułożonych w określonej kolejności, obserwacje, metody projekcyjne oraz metody heurystyczne (tabela 3).

Tabela 3. Wybrane metody badań marketingowych - instrumenty i techniki pomiaru

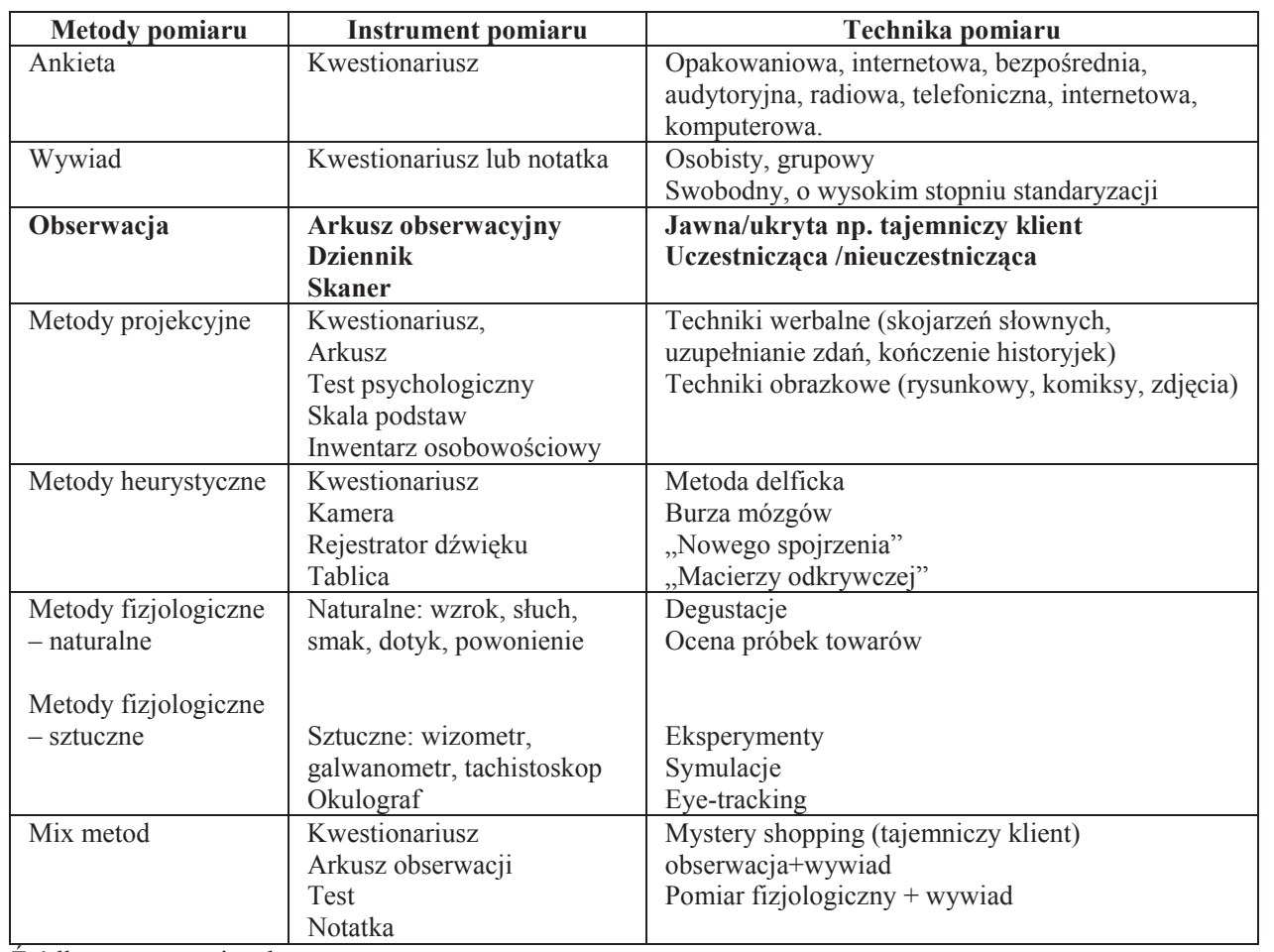

Źródło: opracowanie własne.

\section{Tajemniczy klient jako metoda badawcza}

Wraz z rozwojem gospodarczym i wzrostem zamożności społeczeństw, wzrasta udział rynku usług w Produkcie Krajowym Brutto różnych krajów. Usługi utożsamiane w nomenklaturze marketingowej jako produkty, charakteryzują się szeregiem cech odróżniających je od innych typów produktów, np. dóbr materialnych (samochód, długopis, piłka etc.). Do najważniejszych atrybutów wyróżniających usługi zalicza się:

- Niematerialność,

- Związek z osobą wykonawcy usługi,

- Niemożliwość gromadzenia na zapas,

- Różnorodność,

- Nietrwałość,

- Heterogeniczność. 
Specyfika usługi jako produktu implikuje konieczność monitorowania jej poziomu i jakości. W tym celu wykorzystuje się ankiety o charakterze ciagłym pozostawione w miejscu realizacji usługi (np. w hotelach, serwisach) oraz różnego rodzaju wywiady z konsumentami usług. Wspólną cechą tych metod jest konieczność angażowania respondentów, którzy mogą nie chcieć udzielać informacji. Klasyczne metody stały się zatem niewystarczające, dlatego zaczęto myśleć o wykorzystywaniu nowych. Jedną z nich jest tajemniczy klient. W latach 70 . XX w. koncepcja ta była wykorzystywana w ok. 35 proc. największych banków w Stanach Zjednoczonych. Obecnie metoda tajemniczego klienta w szczególności wykorzystywana jest do ewaluacji jakości świadczenia usług $\mathrm{w}$ bardzo konkurencyjnych branżach, takich jak turystyczna, gastronomiczna czy handel detaliczny ${ }^{11}$. Metoda ta jest formą obserwacji uczestniczącej, wykorzystującej badaczy do odgrywania roli konsumenta lub potencjalnego konsumenta w celu monitorowania procesu i procedur wykorzystywanych w dostarczaniu usług. W Wielkiej Brytanii jest często wykorzystywany przez organizacje usług finansowych, handlu detalicznym, dilerów samochodowych, hotele, catering, transport, zakładów użyteczności publicznej i departamentów rządu ${ }^{12}$. Metoda ta znajduje szerokie wykorzystanie w różnych branżach. Daje też możliwości różnorodnych modyfikacji w jej zastosowaniu, np. można badanie przeprowadzić telefonicznie, za pomoca poczty elektronicznej czy chatów, w celu oceny przestrzegania standardów obsługi. Zaletą metody tajemniczego klienta jest możliwość redukcji potencjalnych wad, które występują w przypadku wywiadów i ankiet. Do najczęściej podkreślanych słabości tych metod zalicza się:

1. Rozbieżność pomiędzy zachowaniem realnym a relacjonowanym. Zdarza się, że oświadczenia udzielane podczas wywiadu nie odpowiadają faktycznym zachowaniom respondenta.

2. Respondent może być nieświadomy pewnych faktów, w związku z czym nie może udzielić oczekiwanych odpowiedzi.

3. Ograniczenie jakości zebranych informacji z powodu niewielkich umiejętności werbalnych respondenta.

Wymienione słabości nie dotyczą badań metodą tajemniczego klienta, jeśli spełnione są następujące warunki metodyczne to jest ${ }^{13}$ :

- anonimowość osoby wykonującej badanie - pracownicy placówki usługowej nie mogą być świadomi odbywającego się procesu badawczego;

- odpowiednio opracowany arkusz obserwacji;

- dobrze wyszkolony badacz, który zapamiętał zdefiniowaną listę ocenianych elementów, na które powinien zwrócić uwagę podczas „tajemniczej” wizyty;

- naturalne zachowanie badacza, po badaniu arkusz musi być wypełniony i przygotowany raport, który jest wykorzystywany dla informacji zwrotnej.

11 K. Schmidt, Mystery Shopping, Leistungsfähigkeit eines Instruments zur Messung der Dienstleistungsqualitat, DUV Gabler Edition Wissenchaft, 2007, s. 3-4.

${ }_{12}$ A.M. Wilson, The Use of Mystery Shhoping in the Measurment of Service Delivery, in: M.Gabbott, G. Hogg (ed.), Serviece Industries Marketing: New Appproaches, Routledge, Francis \& Taylor Group, London and New York, 2013, p. 148-163.

${ }^{13}$ A.M. Wilson, J. Gutmann, Public transport: the role of mystery shopping in investment decisions, Journal of the Market Research Society, 1998, 40 (4), pp. 285-293. 


\section{Metodyka badań}

Celem publikacji jest diagnoza procedur stosowanych $\mathrm{w}$ badaniach marketingowych, a w szczególności wykorzystanie metody tajemniczego klienta w której ocena jest prowadzona przez zespół osób. Dla sprawdzenia tego podejścia zastosowano ocenę grupową jakości usług gastronomicznych wybranych placówek w Warszawie należących do sieci ogólnopolskich lub międzynarodowych. W literaturze przedmiotu oraz praktyce marketingowej metoda tajemniczego klienta, odnosi sie wyłącznie do jednostkowych obserwacji badacza. W prowadzonych badaniach dokonano modyfikacji polegającą na grupowych badaniach usług gastronomicznych. Przyjęta metodyka badań lepiej pozwala zmierzyć jakość tych usług, ponieważ zwykle korzysta się z nich grupowo, wspólnie spędzając wolny czas. Budowanie zespołów, które wspólnie oceniałyby jakość usług, daje możliwość redukcji zróżnicowanej percepcji i różnych doświadczeń osób uczestniczących w badaniu, co ma miejsce w przypadku oceny indywidualnej. Uśrednienie ocen zespołu może tę wadę badania zrównoważyć. Obserwację przeprowadzono przez 20 zespołów składających się z osób w wieku 23-24 lata. Dobór osób w podobnym wieku, o podobnych upodobaniach i doświadczeniach, był celowym działaniem autorów badania i wynikał z chęci redukcji zbyt dużego zróżnicowania oceniających usługę. Łącznie w badaniach uczestniczyło 76 osób. Zespoły odwiedziły następujące placówki gastronomiczne:

- Pizzeria Da Grasso - 5 zespołów-19 osób;

- Bierhalle -4 zespoły-14 osób;

- Bobby Burger - 5 zespołów-20 osób;

- Pizza Hut - 6 zespołów-23 osoby.

Scenariusz badania był ściśle określony. W okresie 14.05.- 1.06.2018 grupy tajemniczych klientów udały się do wylosowanych placówek gastronomicznych w Warszawie. Założeniem było badanie miejsc gastronomicznych w ramach wybranych sieci. Warunkiem było istnienie przynajmniej 5 lokali w ramach sieci na obszarze Warszawy. Wykorzystano metodę obserwacji uczestniczącej, czyli badacz występuje w roli klienta, oraz obserwację bierną poprzez możliwość obserwacji obsługi innych klientów w lokalu. Ocenie podlegało pięć obszarów usług gastronomicznych:

1. Wygląd zewnętrzny placówek i jej otoczenie.

2. Wnętrze placówki

3. Personel.

4. Menu.

5. Miejsca specjalne, np. istnienie miejsca zabaw dla dzieci, miejsca dla osób palących.

Zadaniem każdego zespołu było przeprowadzenie badań w wylosowanej placówki. Dokonanie oceny czy była dobrze oznaczona i widoczna, czy nie było problemów z trafieniem do niej. Przeprowadzenie obserwacji pięciu omówionych wcześniej obszarów, szczegółowo zaprezentowanych w arkuszu obserwacji. Zdobycie odpowiedzi na ustalone w scenariuszu pytania, dotyczące oferty napojów i potraw oraz wizyta w toalecie w celu oceny czystości tego miejsca. Do oceny poszczególnych elementów w każdym obszarze, przyjęto 7-stopniową skalę ( 1- bardzo źle, 7- bardzo dobrze). 


\section{Wyniki badań}

Badania przeprowadzono zgodnie z przyjętym wcześniej scenariuszem. Badacze zostali odpowiednio przeszkoleni w jaki sposób należy przeprowadzić obserwację uczestnicząca, dodatkowo otrzymali szczegółowy spis elementów podlegających ocenie $\mathrm{w}$ trakcie pobytu $\mathrm{w}$ restauracji. Pierwszym obszarem podlegającym obserwacji było otoczenie restauracji. Brano tutaj pod uwagę czytelność oznakowania, czystość najbliższego otoczenia oraz drzwi i witryn. W tym obszarze oceny można stwierdzić wysokie zadowolenie tajemniczych klientów. Problemem był brak parkingów w lokalach znajdujących się w centrum Warszawy. W Bobby Burgerze pojawił się kłopot z dostępnością lokalu dla rodziców z dziećmi w wózkach i osób niepełnosprawnych. Pozostałe elementy zostały ocenione powyżej średniej. Przy czym widać zróżnicowanie ocen dla poszczególnych placówek w ramach jednej sieci. Mimo, że firmowane są tą samą nazwą i teoretycznie standard w ramach franczyzy powinien być taki sam, jednak poszczególne średnie oceny zespołowe wskazują, że na występowanie różnic (patrz tabela 4).

Tabela 4. Ocena wybranych elementów wyglądu zewnętrznego placówek gastronomicznych przez zespoły tajemniczych klientów (1-bardzo źle 7-bardzo dobrze)

\begin{tabular}{|c|c|c|c|c|c|c|c|c|c|c|c|c|c|c|c|c|c|c|c|c|}
\hline \multirow{2}{*}{$\begin{array}{l}\text { OTOCZENIE } \\
\text { PLACÓWEK } \\
\text { GASTRONO- } \\
\text { MICZNYCH }\end{array}$} & \multicolumn{5}{|c|}{ Pizzeria Da Grasso } & \multicolumn{4}{|c|}{ Bierhalle } & \multicolumn{5}{|c|}{ Bobby Burger } & \multicolumn{6}{|c|}{ Pizza Hut } \\
\hline & 1 & 2 & 3 & 4 & 5 & 1 & 2 & 3 & 4 & 1 & 2 & 3 & 4 & 5 & 1 & 2 & 3 & 4 & 5 & 6 \\
\hline $\begin{array}{l}\text { Czystość drzwi i } \\
\text { witryn }\end{array}$ & 3 & 6,5 & 4,4 & 4 & 4,8 & 6 & 5,5 & 5 & 7 & 2 & 5 & 5,5 & 3 & 4,3 & 6 & 4 & 3 & 3,8 & 1 & 6,3 \\
\hline $\begin{array}{l}\text { Informacje o } \\
\text { godzinach } \\
\text { otwarcia }\end{array}$ & 1,3 & 6,5 & 6,8 & 4 & 7 & 7 & 1,5 & 5 & 7 & 7 & 7 & 7 & 7 & 6,8 & 7 & 4 & 2 & 5,5 & 1 & 6,5 \\
\hline $\begin{array}{l}\text { Widoczność } \\
\text { oznaczenia }\end{array}$ & 2 & 6,3 & 5,4 & 5 & 4,8 & 7 & 7 & 5 & 7 & 5 & 5 & 6 & 7 & 7 & 6 & 5 & 2 & 3,5 & 5 & 6,5 \\
\hline $\begin{array}{l}\text { Dostępność lokalu } \\
\text { dla osób } \\
\text { z dziećmi i } \\
\text { niepełnosprawnych }\end{array}$ & 4,5 & 7 & 6,6 & 4 & 6,8 & 3 & 4,5 & 3 & 7 & 3 & 1 & 6 & 1 & 1,3 & 5 & 4 & 1 & 5,5 & 2 & 6 \\
\hline $\begin{array}{l}\text { Czytelność } \\
\text { oznakowania } \\
\text { lokalu }\end{array}$ & 1,8 & 6,3 & 4,2 & 4 & 3 & 7 & 6,8 & 7 & 7 & 6 & 5 & 6,8 & 7 & 5,3 & 6 & 4 & 2 & 3,3 & 6 & 6,3 \\
\hline $\begin{array}{l}\text { Czystość } \\
\text { najbliższego } \\
\text { otoczenia }\end{array}$ & 2 & 7 & 4,4 & 4 & 3,5 & 7 & 2,8 & 5 & 5 & 4 & 4 & $5, .8$ & 5 & 5,8 & 3 & 6 & 4 & 3 & 6 & 5,3 \\
\hline $\begin{array}{l}\text { Dostępność } \\
\text { parkingów }\end{array}$ & 5,3 & 1,3 & 2,6 & 4 & 2 & 1 & 4,8 & 5 & 6 & 1 & 1 & 5 & 4 & 1 & 1 & 4 & 1 & 1,3 & 7 & 6,3 \\
\hline
\end{tabular}

Źródło: badania własne, maj-czerwiec 2018.

Następny obszar oceny związany był z wejściem do placówki gastronomicznej i ewaluacją wnętrza. Ponownie zauważa się duże zróżnicowania pomiędzy lokalami tej samej sieci. Również oceny poszczególnych sieci różniły się. Najlepsze wrażenie na badaczach robiły restauracje Pizza Hut, 2 zespoły oceniły na 7 punktów, a kolejne 2 na 6 punktów. Podobnie oceniono zapach, panujący w restauracjach. Generalnie można powiedzieć, że wszystkie sieci otrzymały oceny średnie i wysokie. Największe problemy zaobserwowano w kwestii: wydzielonych kącików dla dzieci, wydzielonych miejsc dla palaczy oraz czystości w toalecie i wyposażeniu jej w podstawowe akcesoria takie jak: ręczniki papierowe, mydło, papier toaletowy (patrz tabela 5). Subiektywizm i 
indywidualność oceny, stanowiące wadę stosowania metody tajemniczego klienta, najlepiej obrazuje ocena menu. Mimo, że we wszystkich lokalach znajdowała się identyczna karta potraw, to w ramach poszczególnych zespołów, odwiedzających różne palcówki należące do tej samej sieci, widać rozbieżności w ocenach, choć w przeważającej części dominują oceny pozytywne.

Tabela 5. Ocena wybranych elementów wnętrza placówek gastronomicznych przez zespoły tajemniczych klientów

\begin{tabular}{|c|c|c|c|c|c|c|c|c|c|c|c|c|c|c|c|c|c|c|c|c|}
\hline \multirow{2}{*}{$\begin{array}{c}\text { WNETRZE } \\
\text { PLACÓWEK } \\
\text { GASTRONO } \\
\text { MICZNYCH }\end{array}$} & \multicolumn{5}{|c|}{ Pizzeria Da Grasso } & \multicolumn{4}{|c|}{ Bierhalle } & \multicolumn{5}{|c|}{ Bobby Burger } & \multicolumn{6}{|c|}{ Pizza Hut } \\
\hline & 1 & 2 & 3 & 4 & 5 & 1 & 2 & 3 & 4 & 1 & 2 & 3 & 4 & 5 & 1 & 2 & 3 & 4 & 5 & 6 \\
\hline $\begin{array}{l}\text { Pierwsze } \\
\text { wrażenie po } \\
\text { wejściu }\end{array}$ & 2,8 & 5,8 & 3,4 & 3 & 4,8 & 7 & 4,3 & 6 & 6 & 4 & 4 & 4,5 & 6 & 4,8 & 7 & 7 & 6 & 4,3 & 5 & 6 \\
\hline Zapach & 5,8 & 3,5 & 4,8 & 3 & 7 & 6 & 5 & 5 & 6 & 5 & 4 & 3,8 & 4 & 4 & 7 & 7 & 6 & 4,3 & 5 & 6 \\
\hline $\begin{array}{l}\text { Panujący } \\
\text { nastrój }\end{array}$ & 3 & 6 & 3,2 & 3 & 6 & 6 & 5,8 & 6 & 7 & 4 & 4 & 4,5 & 6 & 3,5 & 5 & 7 & 6 & 4 & 4 & 5,8 \\
\hline $\begin{array}{l}\text { Wystrój } \\
\text { wnętrza } \\
\end{array}$ & 2,3 & 5,3 & 3,6 & 4 & 5,3 & 6 & 5,5 & 4 & 7 & 3 & 4 & 5,3 & 6 & 4,8 & 6 & 7 & 4 & 4,5 & 6 & 6 \\
\hline Muzyka w tle & 2 & 5,3 & 5,8 & 1 & 7 & 6 & 5,8 & 4 & 7 & 7 & 6 & 3,8 & 6 & 2 & 4 & 7 & 7 & 4,3 & 1 & 5,3 \\
\hline Czystość & 3 & 6,5 & 2,4 & 4 & 7 & 7 & 4,3 & 5 & 6 & 3 & 5 & 4,5 & 5 & 5,3 & 5 & 5 & 5 & 4,3 & 4 & 6 \\
\hline $\begin{array}{l}\text { Wydzielony } \\
\text { kącik dla } \\
\text { dzieci }\end{array}$ & 4,5 & 5,3 & 1 & 1 & 1 & 1 & 1,5 & 5 & 7 & 1 & 5 & 1 & 3 & 1 & 2 & 1 & 6 & 1,3 & 1 & 1,5 \\
\hline $\begin{array}{l}\text { Wydzielone } \\
\text { miejsce dla } \\
\text { palących }\end{array}$ & 1,5 & 1 & 3 & 1 & 1,5 & 1 & 1 & 1 & 7 & 1 & 4 & 1 & 3 & 1 & 3 & 1 & 5 & 2 & 1 & 5,3 \\
\hline $\begin{array}{l}\text { Zadbane } \\
\text { meble }\end{array}$ & 3,5 & 7 & 3,8 & 4 & 2,5 & 6 & 4,5 & 4 & 7 & 4 & 3 & 4,5 & 5 & 4,5 & 4 & 6 & 4 & 3,8 & 7 & 5 \\
\hline $\begin{array}{l}\text { Czystość } \\
\text { nakrycia }\end{array}$ & 3,8 & 1 & 4,4 & 4 & 4 & 6 & 7 & 4 & 6 & 3 & 5 & 5,8 & 2 & 5,3 & 3 & 6 & 5 & 4,5 & 6 & 6,5 \\
\hline $\begin{array}{l}\text { Dostępność } \\
\text { serwetek }\end{array}$ & 1,8 & 7 & 6,2 & 2 & 7 & 6 & 3,3 & 5 & 7 & 6 & 6 & 4,3 & 5 & 5 & 4 & 4 & 5 & 4,5 & 6 & 4 \\
\hline $\begin{array}{l}\text { Czystość w } \\
\text { toalecie }\end{array}$ & 2 & 5,3 & 5,8 & 4 & 1,8 & 5 & 6,5 & 5 & 4 & 3 & 4 & 3,3 & 2 & 4,5 & 5 & 5 & 4 & 5 & 1 & 1 \\
\hline $\begin{array}{l}\text { Wyposażenie } \\
\text { łazienki: } \\
\text { ręczniki, } \\
\text { mydło itd. }\end{array}$ & 3,8 & 4,3 & 6,2 & 5 & 1,8 & 5 & 7 & 5 & 6 & 3 & 5 & 6 & 5 & 5,5 & 4 & 7 & 6 & 5 & 6 & 1 \\
\hline $\begin{array}{l}\text { Dostępność } \\
\text { Wi-Fi }\end{array}$ & 1 & 6 & 6,8 & 1 & 7 & 6 & 7 & 5 & 6 & 7 & 4 & 6,3 & 5 & 1 & 6 & 7 & 7 & 7 & 6 & 5 \\
\hline Estetyka menu & 5 & 6,3 & 5,8 & 4 & 5,3 & 7 & 3,3 & 6 & 5 & 6 & 6 & 7 & 6 & 3,8 & 7 & 7 & 5 & 5 & 4 & 7 \\
\hline
\end{tabular}

Źródło: badania własne, maj-czerwiec 2018.

Ważnym ogniwem oddziałującym w sposób zasadniczy na ocenę standardu usług jest personel. W tym obszarze skoncentrowano się przede wszystkim na osobie kelnera, jego wyglądzie, zachowaniu i wiedzy na temat serwowanego menu. Badacze zadawali także dodatkowe, ustalone wcześniej pytania. Okazało się, że wiedza kelnerów na temat potraw i serwowanych produktów jest duża, natomiast występowało szerokie zróżnicowanie ocen w kwestii odpowiedniego zachowania się personelu. Wiele osób obsługujących gości, nie przywitało się, często badacze twierdzili, że weszli do placówki i nikt nie zwrócił na nich uwagi. Niewielu kelnerów również nawiązywało i podtrzymywało rozmowę. Dominowały $w$ tych kwestiach oceny na poziomie 1-3 
punktów. Narzekano również na fakt, że personel nie żegnał się z klientami na koniec wizyty, co odzwierciedlają oceny $\mathrm{w}$ tabeli 6 . Nie wszyscy kelnerzy byli zadbani, zdarzało się, że nie mieli estetycznego stroju. Tego zarzutu nie formułowano w stosunku do lokali należących do Pizzy Hut. Najgorsze oceny przyznano pizzeriom Da Grasso. Kelnerzy nie mieli też często żadnych identyfikatorów (tabela 6).

Tabela 6. Ocena wybranych cech personelu

\begin{tabular}{|c|c|c|c|c|c|c|c|c|c|c|c|c|c|c|c|c|c|c|c|c|}
\hline \multirow{2}{*}{$\begin{array}{l}\text { PERSONE } \\
\mathrm{L}\end{array}$} & \multicolumn{5}{|c|}{ Pizzeria Da Grasso } & \multicolumn{4}{|c|}{ Bierhalle } & \multicolumn{5}{|c|}{ Bobby Burger } & \multicolumn{6}{|c|}{ Pizza Hut } \\
\hline & 1 & 2 & 3 & 4 & 5 & 1 & 2 & 3 & 4 & 1 & 2 & 3 & 4 & 5 & 1 & 2 & 3 & 4 & 5 & 6 \\
\hline $\begin{array}{l}\text { Przywitani } \\
\text { e klienta }\end{array}$ & 1 & 5,5 & 1 & 3 & 6,5 & 7 & 5 & 3 & 1 & 6 & 6 & 1,3 & 1 & 4,5 & 7 & 2 & 6 & 1,5 & 7 & 4 \\
\hline $\begin{array}{l}\text { Nawiązani } \\
\text { e rozmowy }\end{array}$ & 1,3 & 4,3 & 1 & 1 & 5,8 & 7 & 5,8 & 4 & 3 & 5 & 3 & 2,8 & 1 & 3,8 & 6 & 2 & 1 & 1,8 & 6 & 2,3 \\
\hline $\begin{array}{l}\text { Podtrzyma } \\
\text { nie } \\
\text { rozmowy }\end{array}$ & 1 & 2,5 & 1 & 1 & 6,8 & 7 & 5,8 & 3 & 3 & 5 & 3 & 1,5 & 4 & 2,5 & 6 & 1 & 1 & 1,3 & 2 & 3 \\
\hline $\begin{array}{l}\text { Pożegnanie } \\
\text { przez } \\
\text { kelnera }\end{array}$ & 2 & 7 & 4,4 & 3 & 2 & 7 & 3,5 & 2 & 1 & 3 & 5 & 1,8 & 6 & 4 & 3 & 3 & 6 & 1,5 & 2 & 5,5 \\
\hline $\begin{array}{l}\text { Fachowość } \\
\text { obsługi }\end{array}$ & 3 & 5 & 4,4 & 3 & 5,8 & 7 & 4,5 & 4 & 1 & 4 & 5 & 3,8 & 5 & 4 & 4 & 3 & 7 & 3 & 5 & 5,5 \\
\hline $\begin{array}{l}\text { Zadbanie } \\
\text { kelnera } \\
\text { (czyste } \\
\text { włosy, } \\
\text { paznokcie } \\
\text { etc.) }\end{array}$ & 4,5 & 5,5 & 3,8 & 5 & 3,3 & 7 & 7 & 4 & 6 & 3 & 5 & 4 & 6 & 5,5 & 6 & 6 & 7 & 4,8 & 7 & 7 \\
\hline $\begin{array}{l}\text { Estetyczny } \\
\text { ubiór } \\
\text { kelnerów }\end{array}$ & 3,8 & 4,8 & 2,8 & 4 & 3,3 & 7 & 5,8 & 4 & 6 & 3 & 5 & 4,3 & 6 & 4,3 & 6 & 6 & 7 & 5 & 7 & 7 \\
\hline $\begin{array}{l}\text { Identyfikat } \\
\text { ory z } \\
\text { imieniem } \\
\text { kelnerów }\end{array}$ & 1 & 7 & 1 & 1 & 5 & 7 & 2,5 & 5 & 7 & 1 & 1 & 1 & 1 & 1 & 3 & 7 & 7 & 4,8 & 1 & 7 \\
\hline $\begin{array}{l}\text { Wiedza } \\
\text { kelnera o } \\
\text { menu }\end{array}$ & 3,3 & 7 & 4,2 & 4 & 3,5 & 7 & 5 & 6 & 6 & 6 & 7 & 4,8 & 6 & 6 & 5 & 5 & 7 & 5,3 & 7 & 5,5 \\
\hline
\end{tabular}

Źródło: badania własne, maj-czerwiec 2018.

Jakość posiłków, przejrzystość menu, spełnienie oczekiwań gościa w kwestii podanej potrawy były wysokie. Badający wykazywali niezadowolenie w kwestii przejrzystości menu, twierdząc często, że były chaotyczne, ,za dużo różnych informacji na jednej stronie karty". Interesujący jest również fakt, że nie we wszystkich restauracjach występowały nazwy dań w innych językach niż polski (patrz tabela 7).

Tabela 7. Ocena wybranych elementów menu przez zespoły tajemniczych klientów

\begin{tabular}{|c|c|c|c|c|c|c|c|c|c|c|c|c|c|c|c|c|c|c|c|c|}
\hline \multirow{2}{*}{ MENU } & \multicolumn{5}{|c|}{ Pizzeria Da Grasso } & \multicolumn{4}{|c|}{ Bierhalle } & \multicolumn{5}{|c|}{ Bobby Burger } & \multicolumn{6}{|c|}{ Pizza Hut } \\
\hline & 1 & 2 & 3 & 4 & 5 & 1 & 2 & 3 & 4 & 1 & 2 & 3 & 4 & 5 & 1 & 2 & 3 & 4 & 5 & 6 \\
\hline $\begin{array}{l}\text { Estetyka } \\
\text { menu }\end{array}$ & 5 & 6,3 & 5,8 & 4 & 5,3 & 7 & 3,3 & 6 & 5 & 6 & 6 & 7 & 6 & 3,8 & 7 & 7 & 5 & 5 & 4 & 7 \\
\hline $\begin{array}{l}\text { Przejrzysto } \\
\text { ść menu }\end{array}$ & 6,5 & 5,5 & 5,2 & 2 & 4 & 6 & 4,3 & 5 & 5 & 6 & 6 & 7 & 6 & 5,8 & 6 & 7 & 4 & 5,3 & 6 & 6,5 \\
\hline $\begin{array}{l}\text { Świeżość } \\
\text { składników }\end{array}$ & 6 & 5,5 & 5 & 3 & 5 & 6 & 7 & 5 & 2 & 7 & 6 & 4,8 & 5 & 5,5 & 5 & 7 & 6 & 2,3 & 7 & 7 \\
\hline $\begin{array}{l}\text { Spełnienie } \\
\text { oczekiwań }\end{array}$ & 4,3 & 3,3 & 4,6 & 3 & 6 & 6 & 6,5 & 7 & 3 & 6 & 6 & 3,3 & 4 & 5,5 & 5 & 5 & 6 & 6 & 7 & 7 \\
\hline
\end{tabular}




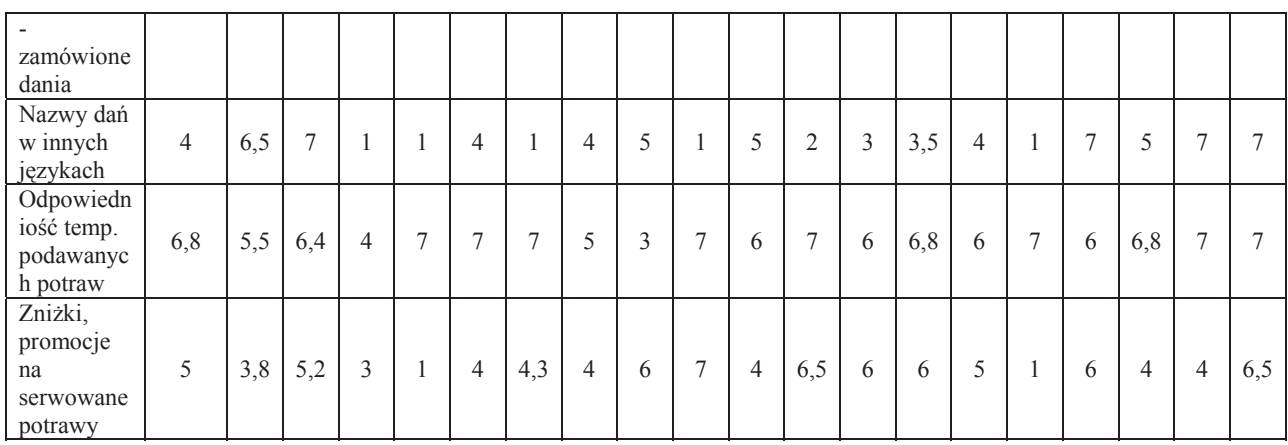

Źródło: badania własne, maj-czerwiec 2018.

Ostatnim obszarem badań były wybrane miejsca dla klientów mających specjalne potrzeby. Byli to rodzice z małymi dziećmi i palacze. Te kwestie oceniono najgorzej, z czego można wnioskować, że oczekiwania klientów z małymi dziećmi czy palących papierosy, nie brane są specjalnie pod uwagę. W większości placówek nie było wyznaczonych oddzielonych, wygodnych miejsc dla palących. Musieli oni sobie sami radzić wychodząc najczęściej na zewnątrz lokalu, co nie było komfortowe dla gości siedzących przy stolikach na świeżym powietrzu. Dla małych dzieci nie było przystosowanych łazienek, w większości przypadków nie było miejsc do przewijania niemowlaków, jeśli były to oceniano je nisko.

Tabela 8. Ocena przygotowania miejsc specjalnych i udogodnień dla klientów

\begin{tabular}{|c|c|c|c|c|c|c|c|c|c|c|c|c|c|c|c|c|c|c|c|c|}
\hline \multirow{2}{*}{$\begin{array}{l}\text { WYBRANE } \\
\text { MIEJSCA } \\
\text { SPECJALNE }\end{array}$} & \multicolumn{5}{|c|}{ Pizzeria Da Grasso } & \multicolumn{4}{|c|}{ Bierhalle } & \multicolumn{5}{|c|}{ Bobby Burger } & \multicolumn{6}{|c|}{ Pizza Hut } \\
\hline & 1 & 2 & 3 & 4 & 5 & 1 & 2 & 3 & 4 & 1 & 2 & 3 & 4 & 5 & 1 & 2 & 3 & 4 & 5 & 6 \\
\hline $\begin{array}{l}\text { Kącik dla } \\
\text { dzieci }\end{array}$ & 4,5 & 5,8 & 1 & 1 & 1 & 1 & 1 & 2 & 1 & 1 & 1 & 1 & 1 & 1 & 2 & 1 & 5 & 1 & 1 & 2,8 \\
\hline $\begin{array}{l}\text { Udogodnienia } \\
\text { dla dzieci }\end{array}$ & 3,5 & 4,3 & 1,6 & 1 & 2 & 3 & 2 & 2 & 2 & 1 & 1 & 1 & 1 & 1 & 3 & 1 & 6 & 3 & 2 & 3,3 \\
\hline $\begin{array}{l}\text { Toaleta } \\
\text { dostosowana } \\
\text { dla osób } \\
\text { niepełnospraw } \\
\text { nych }\end{array}$ & 2,3 & 5,8 & 6,8 & 3 & 2 & 1 & 1 & 3 & 4 & 1 & 1 & 1 & 1 & 1 & 4 & 7 & 1 & 1 & 1 & 1 \\
\hline $\begin{array}{l}\text { Miejsce do } \\
\text { przewijania } \\
\text { dzieci }\end{array}$ & 1 & 1 & 1 & 1 & 1 & 1 & 1 & 1 & 1 & 1 & 1 & 1 & 1 & 1 & 4 & 7 & 6 & 1 & 1 & 1 \\
\hline $\begin{array}{l}\text { Miejsce dla } \\
\text { palących }\end{array}$ & 5,3 & 1 & 2,4 & 3 & 1 & 1 & 1 & 1 & 1 & 1 & 1 & 3 & 3 & 1 & 5 & 7 & 6 & 4 & 1 & 5 \\
\hline
\end{tabular}

Źródło: badania własne, maj-czerwiec 2018.

\section{Podsumowanie i wnioski}

Istotą badań marketingowych jest dostarczanie decydentom informacji i wiedzy, by mogli podejmować trafne decyzje odnoszące się do efektywnego wykorzystywania zasobów i realizacji celów organizacji. Pozyskanie wiedzy uzależnione jest od przyjętego podejścia metodycznego, bazującego na odmiennym widzeniu świata choćby w koncepcji fenomenologicznej lub w pozytywistycznej. Każdy z tych punktów widzenia silnie osadzony jest w filozofii m.in. E. Husserla i jego poglądów na źródła poznania lub A. Comte i jego pozytywistycznym widzeniu świata teorii naukowych. Ten swoisty dualizm badania fenomenologiczne versus badania pozytywistyczne 
zastępowany jest praktycznym spojrzeniem: badania jakościowe akcentowane w paradygmacie fenomenologicznym, oraz badania ilościowe charakterystyczne dla podejścia pozytywistycznego.

Metoda tajemniczego klienta nawiązuje w swojej istocie poznawczej do podejścia fenomenologicznego, w większym stopniu akcentującego wagę badań jakościowych. Metoda ta jest kolejnym wariantem obserwacji uczestniczącej, w przypadku której badacz odgrywa ściśle określoną rolę konsumenta. W praktyce marketingowej, co warte jest tu szczególnego podkreślenia, metoda tajemniczego klienta, odnosi się wyłącznie do jednostkowych obserwacji badacza. Jest to dobry sposób na uzyskanie wiedzy na temat przestrzegania standardów przez personel zatrudniony w restauracji. Jednak dużym problemem może być subiektywizm badacza oraz jego wcześniejsze doświadczenia, związane z konsumpcją określonych usług. Zdaniem Autorów, dobrym sposobem niwelowania tego typu ułomności metody badawczej $\mathrm{W}$ przypadku usług gastronomicznych może być prowadzenie badań przez grupę tajemniczych klientów. Powoduje to po pierwsze uśrednienie indywidualnych ocen każdego członka zespołu, uczestniczącego w badaniu. Po drugie, badanie odbywa się w bardziej naturalnej sytuacji, gdyż zwykle do restauracji ludzie umawiają się w grupie lub conajmniej z drugą osobą, aby wspólnie spędzić czas wolny: porozmawiać, pośmiać się, wymienić poglądy.

W związku z powyższym, autorzy publikacji zmodyfikowali dotychczasowe podejście metodyczne, realizując badanie tajemniczego klienta w zespołach, których zadaniem była - ocena standardu usług gastronomicznych. Potwierdzono w badaniach, że przyjęta metodyka lepiej pozwala zmierzyć jakość usług. Badania prowadzone w zespołach umożliwiły redukcję zróżnicowanej percepcji i różnych doświadczeń osób uczestniczących w badaniu. Subiektywizm i indywidualność oceny, stanowiące wadę stosowania metody tajemniczego klienta, najlepiej obrazuje ocena menu. Mimo, że we wszystkich lokalach jednej sieci znajdowała się identyczna karta potraw, to oceny poszczególnych zespołów, odwiedzających różne palcówki, były rozbieżne.

Badania usług gastronomicznych w warszawskich restauracjach wykazały różnice w świadczeniu usług w przedsiębiorstwach franchisingowych. Oceniając wejście i schludność poszczególnych placówek najlepsze wrażenie na badaczach robiły restauracja: Pizza Hut. Najgorsze wrażenie, a przez to i najniższą punktację otrzymały badane restauracje za brak m.in. wydzielonych miejsc dla palaczy, brak czystości $\mathrm{w}$ toalecie oraz brak podstawowych środków higieny jak: ręczniki papierowe, mydło, papier toaletowy. Najlepiej we wszystkich restauracjach oceniono wiedzę personelu na temat serwowanych potraw. Natomiast wiele zastrzeżeń budziło zachowanie w zakresie przywitania, nawiązania rozmowy i pożegnania gości. Co może świadczyć o niedostatecznych szkoleniach personelu w zakresie sovoir-vivru. Ostatnim, ocenianym przez zespoły obszarem, były wybrane miejsca dla klientów mających specjalne potrzeby. Byli to rodzice $\mathrm{z}$ małymi dziećmi, osoby niepełnosprawne i osoby palące. W większości placówek nie było wyznaczonych oddzielonych, wygodnych miejsc dla palących. Najczęściej musieli wychodzić na zewnątrz, co z kolei sprawiało dyskomfort osobom siedzącym przy stolikach na świeżym powietrzu. Z kolei dla małych dzieci nie było przystosowanych łazienek, w większości przypadków brakowało również wygodnych miejsc do przewijania niemowlaków. Te elementy oceniono w badaniu 
najgorzej, z czego można wnioskować, że oczekiwania klientów z małymi dziećmi czy palących papierosy uwzględniane są w małym stopniu.

\section{Bibliografia}

Crouch S., Housden M., Marketing Research for Mangers, Routledge Francis and Taylor 2003.

Hensel P., Glinka B., Teoria ugruntowana, w: Badania jakościowe. Podejścia i teorie, tom 1, Wyd. Naukowe PWN, Warszawa 2012.

Judycki S., Epistemologia XX wieku: przegląd stanowisk, Roczniki Filozoficzne, 1998/1999, 46/47.

Marketing research tools and techniques, Nigel Bradley, Oxford University Press, 2013.

Parasuraman A., Dhruv Grewal, R. Krishnan, Marketing Research, Houghton Mifflin Company, Boston, New York, 2011, p. 56.

Schmidt K., Mystery Shopping, Leistungsfähigkeit eines Instruments zur Messung der Dienstleistungsqualitat, DUV Gabler Edition Wissenchaft, 2007.

Schmidt M.J., S. Hollenson Marketing research. An international approach, FT Prentice Hall, 2006, Marketing research, tools and techniques, Nigel Bradley, Oxford University Press, 2013.

Silverman D., Interpretacja danych ilościowych, Wyd. Naukowe PWN, Warszawa, 2009.

Szacki J., Historia myśli socjologicznej, Wyd. Naukowe PWN, Warszawa 2012.

Wilson A.M., Gutmann J., Public transport: the role of mystery shopping in investment decisions, Journal of the Market Research Society, 1998, 40 (4).

Wilson A.M., The Use of Mystery Shhoping in the Measurment of Service Delivery, in: M. Gabbott, G. Hogg (ed.), Serviece Industries Marketing: New Appproaches, Routledge, Francis \& Taylor Group, London and New York, 2013.

Zahavi D., Femonologia Husserla, Wyd. WAM, Kraków 2012.

Mazurkiewicz-Pizło A., Pizło W., Marketing, Wiedza ekonomiczna i aktywność na rynku, wyd. Naukowe PWN, Warszawa 2017.

\section{Summary}

The specificity of services implies the need to monitor their quality. Methods for assessing non-consumer services are constantly sought after. The mystery client method is one of them. The purpose of this publication is to diagnose the procedures used in marketing research, and in particular to use the mysterious client method in which the assessment is conducted by a team of people. To verify this approach, the quality assessment of gastronomic services was used in selected restaurant chains, such as Pizza Hut, Pizzeria Da Grasso, Bobby Burger and Bierhalle. The innovation in the study was the use of group to evaluate services. The adopted methodology allowed to conduct the study in close to real conditions, because usually people go to a restaurant together. Building teams that would jointly assess the quality of services gives also the opportunity to reduce the diversification in perception and different experiences of people participating in the study.

Informacja o autorach:

Dr inż. Anna Mazurkiewicz-Pizło

Akademia Wychowania Fizycznego Józefa Piłsudskiego w Warszawie

e-mail: annamazurkiewiczpizlo@gmail.com

ORCID: 0000-0001-8273-2229 
Dr hab. inż. Wojciech Pizlo, prof. SGGW

Szkoła Główna Gospodarstwa Wiejskiego w Warszawie,

Katedra Polityki Europejskiej i Marketingu,

ul. Nowoursynowska 166, 02-787 Warszawa,

e-mail: wojciech_pizło@sggw.pl

ORCID: 0000-0002-5212-0990 